\title{
Delayed reimplantation of an avulsed central incisor: A 12-year follow-up
}

\author{
Hatice Büyüközer Özkan,' 마 Nezahat Arzu Kayar² \\ 'Department of Endodontics, Alanya Alaaddin Keykubat University Faculty of Dentistry, Antalya, Turkey \\ 2Department of Periodontology, Akdeniz University Faculty of Dentistry, Antalya, Turkey
}

The present case highlights the 12-year follow-up of delayed replantation of a maxillary central incisor which was avulsed due to trauma. The complications seen in the present case were ankylosis and replacement resorption. Clinically, the tooth was asymptomatic and in infraocclusion; however, esthetics was maintained. Information on the long-term outcome and prognosis of surface treatment by the application of tetracycline $\mathrm{HCl}$ is lacking and this case report highlights the result of root surface treatment with tetracycline $\mathrm{HCl}$.

Keywords: Avulsion, permanent tooth, root resorption.

\section{Introduction}

Tooth avulsion is defined as complete displacement of the tooth from its alveolar socket after traumatic injury and requires more attention and follow-up care. Although dentoalveolar injuries are most commonly observed in children and adolescents, particularly boys, they may affect individuals of any age (1-3).

The deal procedure in the case of avulsion is the immediate reimplantation of the tooth into its socket, which warrants the vitality of the structures adhered to the root surface. Periodontal ligament (PDL) healing by reattachment of its fibers to the root surface occurs only when cell viability is maintained (4). In most situations, the conditions are not so favorable and the avulsed teeth are exposed to a dry medium for long periods, PDL necrosis may ensue which may start an external root resorption process $(2,5)$.
The contamination of delayed reimplanted teeth can be controlled by the treatment of root surface and administration of systemic antibiotics. Recently, the use of chemotherapeutic agents has been advocated to manipulate external root resorption pharmacologically (6-9). In experimental animal studies $(6,7)$, tetracycline has been shown to be effective in preventing or attenuating external root resorption when applied systemically and/or topically.

This case report presents the clinical and radiographic conditions of a reimplanted incisor after 12 years. The root surface was immersed in tetracycline $\mathrm{HCl}$ although the tooth was stored under dry conditions for 1 day after the avulsion injury.

\section{Case Repont}

An 18-year-old boy presented to the clinics for emergency treatment due to an avulsed tooth 1 day after a traffic acci- 
dent. The avulsed tooth was retrieved and kept in dry conditions. The patient had already been seen by the medical staff of the emergency unit of a local hospital who had detected no neurological damage or medical complications. Intraoral examination revealed that the dental socket of the upper left permanent central incisor (tooth \#21) was full of blood clot. The periapical radiograph in Figure 1 shows that tooth \#21 is completely avulsed. The oral hygiene of the patient was not favorable and intraoral soft tissues had pathological signs. The occlusion was normal with no missing teeth, and the patient had no caries. The adjacent teeth (\#11 and \#22) of the avulsed tooth were slightly tender to percussion and exhibited mobility within normal limits. Electronic pulp testing and cold application (ice stick) yielded positive vitality for both teeth. Based on these findings, the patient was diagnosed as having an avulsed tooth due to dental trauma. Afterwards, the patient was informed of the long-term prognosis of the tooth, and a decision was made to perform root canal treatment (RCT) extraorally and to place the tooth in its socket.

At the same appointment, RCT was initiated on tooth $\# 21$. Access cavity was prepared, necrotic pulp tissue was extirpated, and the root canal was instrumented with size 15-40 K-files (Dentsply-Maillefer, Ballaigues, Switzerland) using a step-back technique. During the instrumentation, the canal was irrigated with $2.5 \% \mathrm{NaOCl}$ and normal saline solution using a 27 -gauge endodontic needle after each file. The canal was dried with sterile paper points and filled with gutta-percha and a calcium hydroxidebased sealer (Sealapex; Kerr, Romulus, MI, USA) using the cold lateral condensation technique. Later, the access cavity was filled with a composite (Clearfil; Kuraray, Tokyo, Japan) restoration (Figure 1).

The necrotic and dried remnants of periodontal tissue on the root surface were carefully removed with a scaler (Figure 1). Then, tetracycline $\mathrm{HCl}$ was applied for $5 \mathrm{~min}$ on the root surface. Local anesthesia with $2 \%$ articaine containing 1:20.000 epinephrine (Ultracain DS; Sanofi, Istanbul, Turkey) was administered and the alveolar socket was gently curetted to remove any coagulum, granulation tissue, and pathologic tissue and irrigated with physiologic saline solution. The teeth were placed into the extraction sockets and splinted with composite resin (Clearfil; Kuraray, Tokyo, Japan) from the mesial and distal contact ar-
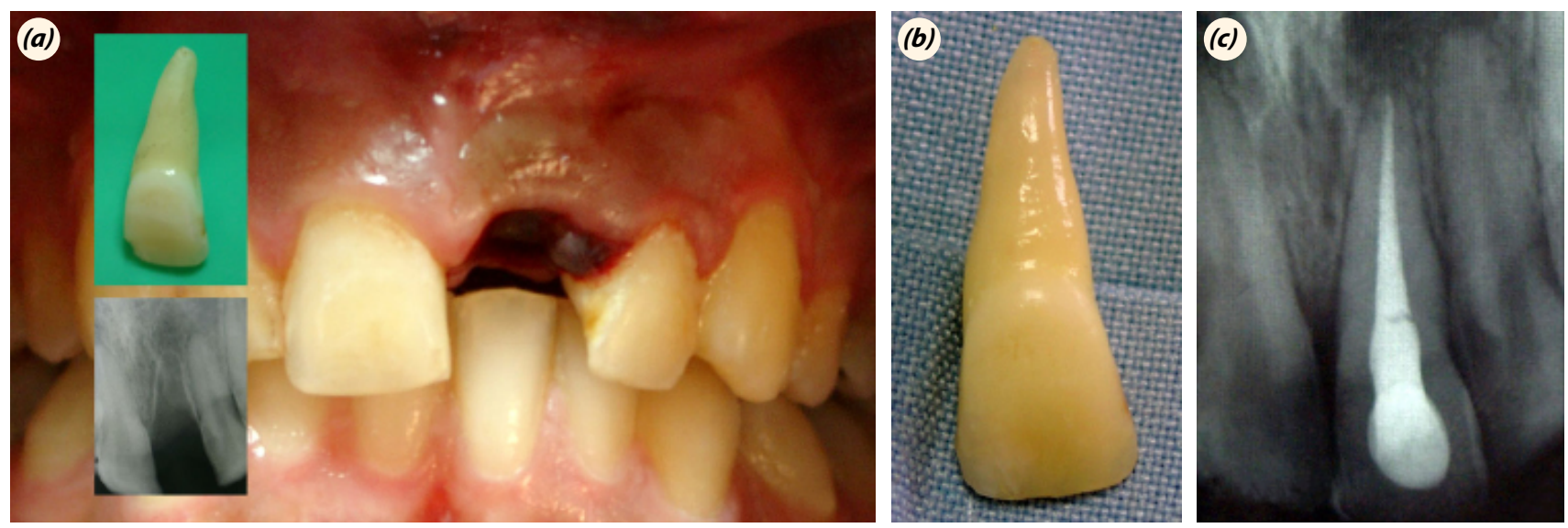

Fig. 1. (a) Extraoral, intraoral, and radiographic views, (b) after root scaling, (c) after root canal treatment.
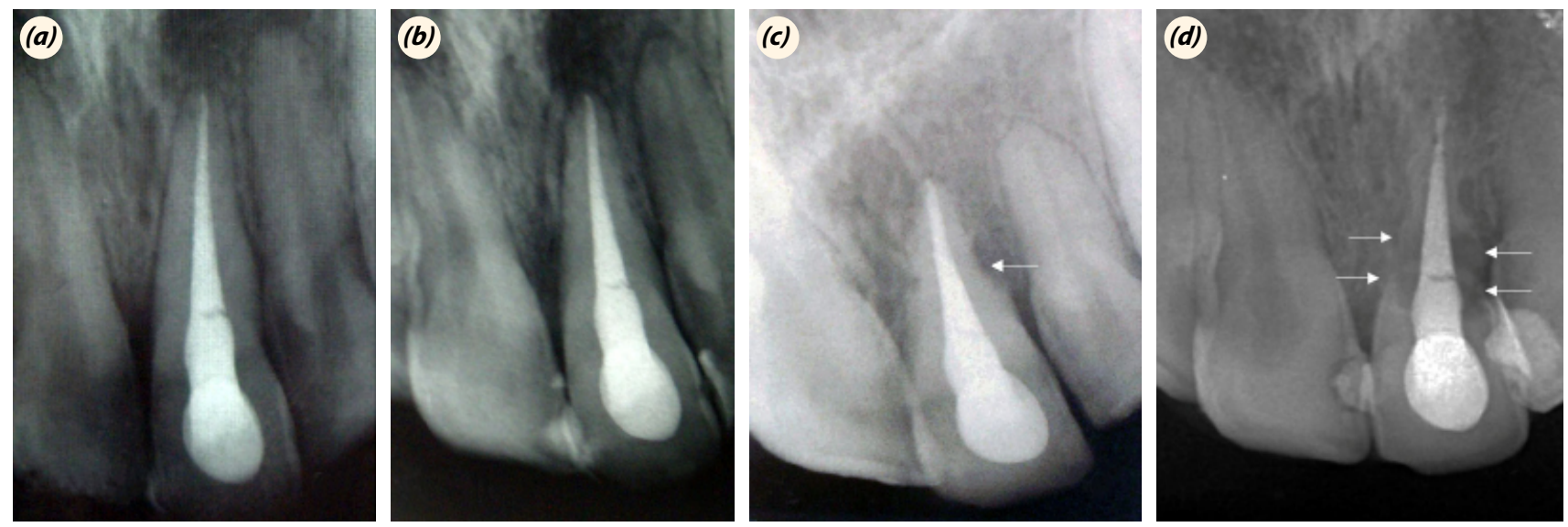

Fig. 2. (a) Three-month recall, (b) 6-month recall, (c) 22-month recall. Arrow: Early root resorption, (d) 12-year recall. Arrows: Advanced root resorption. 
eas. Moreover, oral hygiene instructions and advice was given about a soft diet and the need to use a chlorhexidine (Klorhex; Drogsan, Ankara, Turkey) mouth rinse during the stabilization period. Doxycycline was prescribed for prophylactic antibiotic therapy and an analgesic was given to be administered for 5 days. The splint was removed at the $6^{\text {th }}$ week.

Radiographs were taken at 3-, 6-, 22-months, and 12-year after replantation for the control of the tooth and healing (Figure 2). During the 22-month recall, there was radiographic evidence of slight surface root resorption (Figure 2 ); however, the tooth was still functioning. There was also no periodontal pocket with pathological signs. After 12 years, the resorption was detected to increase and ankyloses was evident. On the other hand, the tooth was clinically asymptomatic.

The patient did not attend any further follow-ups. Nevertheless, the tooth was preserved successfully for 12 years.

\section{Discussion}

Avulsion causes rupture of the neurovascular bundle, leading to pulp necrosis, which facilitates bacterial contamination in mature teeth. RCT is thus required in case of avulsed teeth (10). In this case, we performed RCT extraorally and filled the canal with gutta-percha and a calcium hydroxide-based sealer using the cold lateral condensation. The avulsed tooth was replanted $24 \mathrm{~h}$ after the accident. When the extra-oral time in avulsion cases is $>60$ min, PDL cells do not survive, and dentoalveolar ankylosis and osseous replacement of the tooth can be observed (9). It has been shown that chemical or mechanical removal or treatment of the necrotic cemental PDL leads to the occurrence of more areas of ankylosis rather than replacement resorption (11-13). In this case, the root surface was scaled from the necrotic PDL tissue and tetracycline $\mathrm{HCl}$ was applied for $5 \mathrm{~min}$. on the root surfaces. It is suggested that that roots should be chemically treated with $2.4 \%$ acidulated sodium fluoride solution ( $\mathrm{pH} 5.5$ ) for 20 min or immersed in tetracycline for 5 min before replantation after the removal of necrotic PDL (14). The action of tetracycline on microorganisms on the contaminated root surface during the extra-alveolar period has been previously investigated. Although it had no effect on the microorganisms present in the necrotic pulp tissue, tetracycline was shown to reduce the occurrence of ankylosis and inflammatory resorption (14). Tetracycline studies $(15,16)$ demonstrate multiple beneficial properties toward regeneration, good anti-collagenase activity, high substantivity, induced bone resorption, and anti-inflammatory action. In addition, it has been indicated that tetracycline is absorbed and subsequently desorbed from dentin, main- taining its antimicrobial activity (17-19). It was recently shown that tetracycline $\mathrm{HCl}$ which acts in an acidic $\mathrm{pH}$ (1.8) was used as the root biomodification agent. Surface demineralization with tetracycline $\mathrm{HCl}$ enhances binding of matrix proteins to dentinal collagen matrix and stimulates fibroblast attachment and growth (20).

Furthermore, several substances have been used for the treatment of the root surface of replanted teeth to increase their retention rate, namely, formol, acid solutions (such as citric acid, hydrochloric acid, acidulated fluoride, and neutral fluoride), alkaline substances (such as calcium hydroxide and $\mathrm{NaOCl}$ ), antibiotics (such as tetracycline and rifocin), antibiotic/corticosteroid combination, corticosteroid, alendronate, Vitamin C, carbonic anhydrase inhibitor (acetazolamide), Cathepsin K, propolis, and Emdogain $(21,22)$.

After these procedures, the tooth was replanted and splinted. To achieve replacement root resorption, the avulsed incisor was splinted to adjacent teeth for 6 weeks to facilitate rapid, solid ankylosis (23).

Replacement resorption is the substitution of dental tissue by bone tissue. Loss of PDL and bone tissue incorporation onto the root surface ends up including the mineralized dental tissue into the resorbed area as part of the bone remodeling process. Dentoalveolar ankylosis may occur after PDL loss and its replacement by bone tissue, thus leaving the root surface in direct contact with the alveolar bone $(2,24)$.

After intraoral procedures were completed, semisynthetic doxycycline, analgesics, and chlorhexidine gluconate mouthwash were prescribed for 5 days. The goal of antibiotic therapy is to avoid bacterial proliferation in the area of the ongoing repair process and contributes to the prevention of inflammatory resorption. Ideally, a broad-spectrum antibiotic should be administered for 7 days (7). Gomes et al. (25) showed that when using antibiotics orally (amoxicillin and tetracycline), the acute inflammatory infiltrate was less intense regardless of the duration of use, and root resorption presented smaller extent and depth.

\section{Conclusions}

There are many treatment protocols for the delayed replantation of the tooth, but the best choice is yet unclear. Although complications such as ankylosis or root resorption may be unavoidable, delayed reimplantation of avulsed tooth may be a good alternative to prosthesis (implant or fixed partial denture) due to the preservation of the alveolar bone and other benefits. Further research and reports on the influence of tetracycline in avulsion are warranted to better highlight the topic. 
Authorship Contributions: Concept: H.B.Ö., N.A.K.; Design: H.B.Ö.; Supervision: H.B.Ö., N.A.K.; Materials: H.B.Ö., N.A.K.; Data: H.B.Ö.; Analysis: H.B.Ö.; Literature search: H.B.Ö.; Writing: H.B.Ö., N.A.K.; Critical revision: H.B.Ö.

Acknowledgements: Special thanks to Prof. Dr. Kürşat Er and Prof. Dr. Funda Kont Çobankara for their professional support and help.

Source of Fundingः None declared.

Conflict of Interest: None declared.

Informed consent: Written informed consent was obtained from patients who participated in this study.

\section{References}

1. Moule A, Cohenca N. Emergency assessment and treatment planning for traumatic dental injuries. Aust Dent J 2016; 61 Suppl 1:21-38. [CrossRef]

2. Andreasen JO, Andreasen FM. Textbook and color atlas of traumatic injuries to the teeth. Copenhagen: Blackwell Munksgaard; 2008.

3. Panzarini SR, Saad-Neto M, Sonoda C, Poi WR, Perri De Carvalho AC. Dental avulsion in young and adult patients in the region of Araçatuba. Rev Assoc Paul Cir Dent 2003; $57: 27-31$.

4. Rajakeerthi R, Nivedhitha MS. Natural product as the storage medium for an avulsed tooth-a systematic review. Cumhuriyet Dent J 2019; 22: 249-56. [CrossRef]

5. Andreasen JO. Effect of extra-alveolar period and storage media upon periodontal and pulpal healing after replantation of mature permanent incisors in monkeys. Int J Oral Surg 1981; 10: 43-53. [CrossRef]

6. Cvek M, Cleaton-Jones P, Austin J, Lownie J, Kling M, Fatti P. Effect of topical application of doxycycline on pulp revascularization and periodontal healing in reimplanted monkey incisors. Endod Dent Traumatol 1990; 6: 170-6.

7. Sae-Lim V, Wang CY, Choi GW, Trope M. The effect of systemic tetracycline on resorption of dried replanted dogs' teeth. Endod Dent Traumatol 1998; 14: 127-32. [CrossRef]

8. Trope M. Avulsion of permanent teeth: theory to practice. Dent Traumatol 2011; 27: 281-94. [CrossRef]

9. Andersson L, Andreasen JO, Day P, et al. International Association of Dental Traumatology. International Association of Dental Traumatology guidelines for the management of traumatic dental injuries: 2. Avulsion of permanent teeth. Dent Traumatol 2012; 28: 88-96. [CrossRef]

10. Flores MT, Andreasen JO, Bakland LK, et al. International Association of Dental Traumatology. Guidelines for the evaluation and management of traumatic dental injuries. Dent Traumatol 2001; 17: 97-102. [CrossRef]

11. Maslamani M, Almusawi A, Joseph B, Gabato S, Anders- son L. An experimental model for studies on delayed tooth replantation and ankylosis in rabbits. Dent Traumatol 2016; 32: 443-9. [CrossRef]

12. Lindskog S, Pierce AM, Blomlof L, Hammarstrom L. The role of the necrotic periodontal membrane in cementum resorption and ankylosis. Endod Dent Traumatol 1985; 1 : 96-101, [CrossRef]

13. Percinoto C, de Campos Russo M, Lima JE, Andrioni JN, Benfatti SV, Bertoz FA. Repair process in replanted teeth after chemical removal of periodontal root fibers. [Article in Portuguese]. Rev Odontol UNESP 1988; 17: 73-81.

14. Sonoda CK, Poi WR, Okamoto T, Toyota E, Takeda RH. Mediate teeth reimplantation after root treatment with $1 \%, 2,5 \%, 5 \%$ and $10 \%$ sodium hypochlorite solution. Rev Bras Odontol 2000; 57: 293-6.

15. Selvig KA, Bjorvatn K, Claffey N. Effect of stannous fluoride and tetracycline on repair after delayed replantation of root-planed teeth in dogs. Acta Odontol Scand 1990; 48; 107-12. [CrossRef]

16. Ingman T, Sorsa T, Suomalainen K, et al. Tetracycline inhibition and the cellular source of collagenase in gingival crevicular fluid in different periodontal diseases. A review article. J Periodontol 1993; 64: 82-8. [CrossRef]

17. Seymour RA, Heasman PA. Tetracyclines in the management of periodontal diseases. A review. J Clin Periodontol 1995; 22: 22-35. [CrossRef]

18. Mohammadi Z. Local applications of tetracyclines in endodontics and dental trauma: a review. Dent Today 2009; 28: 95-6, 98, 100-1; quiz 101.

19. Demirel K, Baer PN, McNamara TF. Topical application of doxycycline on periodontally involved root surfaces in vitro: comparative analysis of substantivity on cementum and dentin. J Periodontol 1991; 62: 312-6. [CrossRef]

20. Silva AC, Moura CC, Ferreira JA, Magalhães Dd, Dechichi P, Soares PB. Biological effects of a root conditioning treatment on periodontally affected teeth-an in vitro analysis. Braz Dent J 2016; 27: 160-8. [CrossRef]

21. Gulinelli JL, Panzarini SR, Fattah CM, et al. Effect of root surface treatment with propolis and fluoride in delayed tooth replantation in rats. Dent Traumatol 2008; 24: 651-7.

22. Kwon Y, Ko H, Kim S, Kim M. The effect of cathepsin K inhibitor surface treatment on delayed tooth replantation in dogs. Dent Traumatol 2018; 34: 201-7. [CrossRef]

23. Cobankara FK, Ungor M. Replantation after extended dry storage of avulsed permanent incisors: report of a case. Dent Traumatol 2007; 23: 251-6. [CrossRef]

24. Trope M. Root resorption of dental and traumatic origin: classification based on etiology. Pract Periodontics Aesthet Dent 1998; 10: 515-22.

25. Gomes WD, Silva CA, Melo ME, et al. Delayed tooth replantation in rats: effect of systemic antibiotic therapy with amoxicillin and tetracycline. Dent Traumatol 2015; 31: 448-56. [CrossRef] 